\title{
Optimization of novel hyperthermostable $\beta$ amylase production by Bacillus subtilis DJ5 using solid agroresidual substrates
}

\author{
A. Poddar - S. C. Jana
}

Received: 17 January 2012/Revised: 3 January 2013/Accepted: 16 March 2013/Published online: 17 April 2013

(C) Islamic Azad University (IAU) 2013

\begin{abstract}
Eight different low cost starchy agroresidues namely Barley (B), Wheat bran (WB), Sattu (S), Rice powder (RP), Corn flour (CF), Rice husk (RH), Yellow peas split (YPS) and arrowroot (A) were used for solid culturing of Bacillus subtilis DJ5 for production of novel hyperthermostable $\beta$ amylase. Various process parameters like initial moisture content, inoculum load, medium $\mathrm{pH}$ and incubation temperature affecting enzyme production were optimized to ensure maximum enzyme yield. Only $10 \%$ inoculums load and medium $\mathrm{pH}$ of 6.9 was found sufficient to achieve maximum enzyme production in all substrates in a decreasing order, $\mathrm{B}>\mathrm{WB}>\mathrm{S}>\mathrm{RP}>$ $\mathrm{CF}>\mathrm{RH}>\mathrm{YPS}>\mathrm{A}$. Optimum $\beta$ amylase production was highly dependent on initial moisture content of substrate as observed from varying requirement of moisture for different substrates. Only $50 \%$ moisture was sufficient for maximum enzyme production of $84.29 \mathrm{U} / \mathrm{gdm}$ in $\mathrm{CF}$. For B, RH, YPS, and A $60 \%$ initial moisture resulted in higher production of $120.34,35.19,26.59$, and $21.58 \mathrm{U} /$ $\mathrm{gdm}$, respectively, at $37{ }^{\circ} \mathrm{C}$. However, for $\mathrm{S}$ and RP higher (70\%) moisture content allowed 113.4 and $85.56 \mathrm{U} / \mathrm{gdm}$ enzyme production, respectively. Under optimized conditions, maximum $\beta$ amylase production was observed after $25 \mathrm{~h}$ for A, YPS, RH, RP; $41 \mathrm{~h}$ for B, WB, CF, and $45 \mathrm{~h}$ for $S$.
\end{abstract}

Keywords Agroresidues - Barley · Moisture content . Wheat bran

A. Poddar · S. C. Jana $(\square)$

P.G. Department of Microbiology, Bidhannagar College

(Govt. of West Bengal), EB 2, Salt Lake City,

Kolkata 700064, West Bengal, India

e-mail: subhasjana1959@gmail.com

\section{Introduction}

Advancement of science and technology in the agricultural field has successfully accumulated huge amount of crops and crop residues. Improper preservation and lack of proper management of these residues is posing a serious threat to the environment (Gustavsson et al. 2011). Beside human consumption, large parts are being used as cattle feed, power generation, still huge amount of crop residues are left unutilized (Parfitt et al. 2010). It must be managed in other ways to reduce wastage and environmental pollution. In a view to proceed in that direction, microbiologists have successfully used solid state fermentation (SSF) to convert agroresidues into economically important value added products (Pandey et al. 1999; Pandey and Soccol 2000; Kim and Dale 2004; Haddadin et al. 2001) that not only the helps in waste management (Pandey et al. 2000a, $\mathrm{b}, \mathrm{c})$, but also strengthen economy of a country.

History tells us that SSF technology was initiated early with the civilization as the process is less complicated, requires minimum process monitoring. SSF process is carried out on a non-soluble material that acts both as physical support and as source of nutrients in absence of free flowing water (Pandey 2003). SSF offers numerous advantages over submerged fermentation $(\mathrm{SmF})$ in processing of agro-industrial residues as it has low capital investment, lower levels of catabolite repression (González and Torres 2006) and end product inhibition, low wastewater output, better product recovery, and high quality production (Lonsane et al. 1985) and are environmentally friendly.

During the last decade, an increased attention was paid to the use of various agro-industrial wastes for amylase production using SSF (Alva et al. 2007). Amylases being the most important industrial enzymes have found a wide 
variety of applications in food, detergent, textile, paper, confectionery, baking, and pharmaceutical industries (Sivaramakrishnan et al. 2006). These enzymes account for about $30 \%$ of the world's enzyme production (van der Maarel et al. 2002).

Several agroresidues like wheat bran, rice husk, oil cakes, etc., have been tested either separately or in combination in SSF for production of alpha amylase (Gangadharan et al. 2006; Balkan and Ertan 2007). In such pursuit of $\alpha$ amylase, $\beta$ amylase was continuously ignored though it has found wide applications in enzyme industry (Ray and Nanada 1996). Reports on $\beta$ amylase production using agroresidues by SSF are very scanty that has left an open avenue to exploit the feasibility of $\beta$ amylase production by SSF.

In our previous study, we have already reported production of hyperthermostable $\beta$ amylase from Bacillus subtilis DJ5 (Poddar et al. 2011a). The enzyme showed remarkable thermostability being fully active at $121{ }^{\circ} \mathrm{C}$ for $15 \mathrm{~min}$. Previously, a thermostable $\beta$ amylase was isolated from Clostridium thermosulfurogenes by Shen et al. (1988) that was stable at $80{ }^{\circ} \mathrm{C}$. Since thermostability is the crucial criteria for industrial application (Haki and Rakshit 2003), $\beta$ amylase of this study has got a leading edge over all previously reported $\beta$ amylase. Moreover, this enzyme is capable of digesting raw starches (Poddar et al. 2011b). This passively illuminates possibilities of using the organism in SSF technology to secret hyperthermostable $\beta$ amylase. The importance of enzymatic saccharification of raw starches without thermal gelatinization is gaining popularity as this process saves energy and reduces cost of starch processing (Shiau and Hung 2003) and makes process simple (Achi and Njoku-Obi 1992). With such background, we have used B. subtilis DJ5 in SSF and used several agro-waste residues separately to determine best substrate for production of $\beta$ amylase. The work was initiated on October 2010 in P.G. Department of Microbiology, Bidhannagar College and continued 7 months long. Several process parameters affecting enzyme production were evaluated and optimized at that time to determine best fermentation condition.

\section{Materials and methods}

\section{Microorganisms}

One mutated strain of B. subtilis DJ5 (GenBank Accession Number GU357825) (Poddar et al. 2011b) was used in this study. The organism was isolated from kitchen waste and was subsequently mutated in our laboratory. The organism was maintained on starch peptone agar medium with the following composition (gram per liter): peptone 0.9,
$\left(\mathrm{NH}_{4}\right)_{2} \mathrm{HPO}_{4} \quad 0.4, \mathrm{KCl} \quad 0.1, \mathrm{MgSO}_{4} \cdot 7 \mathrm{H}_{2} \mathrm{O} \quad 0.1, \quad \mathrm{NaH}_{2-}$ $\mathrm{PO}_{4} \cdot 2 \mathrm{H}_{2} \mathrm{O} 0.5$, soluble starch (Sigma, USA) 5, agar-agar 15, and $\mathrm{pH} 6.9$.

Inoculum preparation

Initial study indicated that $B$. subtilis DJ5 is producing maximum enzyme only at six and half hour in starch peptone broth during SmF. For SSF study, such highly active cells were harvested by inoculating $6 \%$ of $24 \mathrm{~h}$ broth culture in fresh sterile $100-\mathrm{ml}$ starch peptone broth in a rotary shaker at $160 \mathrm{rpm}$ at $37^{\circ} \mathrm{C}$. Active cells were prepared nutrient free by centrifuging the cells at $8,000 \mathrm{rpm}$ for $10 \mathrm{~min}$ and dissolving in same amount of sterile $0.1 \mathrm{M}$ phosphate buffer ( $\mathrm{pH}$ 6.9). It was used as inoculum for SSF. By serial dilution and plating, the number of viable colonies in the inoculum was found to be $3 \times 10^{8} \mathrm{CFU} / \mathrm{mL}$.

Selection of substrate

Selection of a proper substrate is a key aspect of SSF. In SSF, solid material is non-soluble that acts both as physical support and as source of nutrients. Solid material could be a naturally occurring solid substrate such as agricultural crops, agro-industrial residues or inert support (Pandey et al. 2000c, d; Pandey et al. 2001; Peralta-Perez et al. 2001; Hoogschagen et al. 2001).

In an attempt to choose a potential substrate for SSF for $\beta$ amylase production, eight different starchy agricultural products namely barley (B), sattu (S), wheat bran (WB), corn flour (CF), arrowroot (A), yellow peas split (YPS), rice husk $(\mathrm{RH})$, and rice powder (RP) were screened individually.

\section{Solid state fermentation}

Solid substrates were purchased from local market and grinded to make fine powder. $5 \mathrm{gm}$ of substrate was taken in $250 \mathrm{~mL}$ Erlenmeyer flask and was autoclaved at $121^{\circ} \mathrm{C}$ for $20 \mathrm{~min}$. It was then dried in an oven at $80{ }^{\circ} \mathrm{C}$ for $24 \mathrm{~h}$. To maintain desired moisture level ( $\%$ by mass per volume), sterile $0.1 \mathrm{M}$ phosphate buffer ( $\mathrm{pH}$ 6.9) was added aseptically and mixed thoroughly. Culture equivalent to $6 \%$ inoculum load of $\mathrm{SmF}$ were added to it, mixed thoroughly and incubated at $37{ }^{\circ} \mathrm{C}$ for $48 \mathrm{~h}$.

Unless it is specified otherwise, $0.5 \mathrm{gm}$ of fermented mass was mixed with $2.5 \mathrm{~mL}$ of extraction buffer $(0.1 \mathrm{M}$ phosphate buffer pH 6.9 mixed with $0.1 \%$ Tween 80), vortexed well and centrifuged at $10,000 \mathrm{rpm}$ at $15 \mathrm{~min}$ at $4{ }^{\circ} \mathrm{C}$. Supernatant was used as a source of crude enzyme for enzyme assay. 
Optimization of process parameters

Various process parameters affecting enzyme production during SSF were optimized. Each parameter was optimized independently of the other and subsequently optimal conditions were employed in all experiments.

In a sequential order, tested process parameters were initial moisture content $(50,60$, and $70 \%$ by mass per volume), inoculum concentration $(10,20$, and $30 \%$ by volume per mass), medium $\mathrm{pH}(5,6.9$, and 10$)$ and incubation temperature $\left(37\right.$ and $\left.45^{\circ} \mathrm{C}\right)$.

\section{Enzyme assay}

$\beta$ Amylolytic activity was measured by the method described by Bernfeld (1955). Assay mixture contained $0.5 \mathrm{~mL}$ of $0.1 \mathrm{M}$ phosphate buffer ( $\mathrm{pH} 6.9$ ), $1 \mathrm{~mL}$ soluble starch ( $0.5 \%$, Sigma, USA), and $0.1 \mathrm{~mL}$ of enzyme. Control was prepared as same without adding substrate. The reaction mixture was incubated at $100{ }^{\circ} \mathrm{C}$ for $15 \mathrm{~min}$. Enzyme-substrate reaction was then stopped by addition of $1 \mathrm{~mL} 2 \mathrm{M} \mathrm{NaOH}$. Both the assay mixture and control were then allowed to boil in boiling water bath for $10 \mathrm{~min}$ after addition of $0.5 \mathrm{~mL}$ of 3,5-dinitrosalisylic acid reagent (Merck, Germany). After cooling the assay mixture at room temperature, absorbance were measured spectrophotometrically (Elico, India) at $540 \mathrm{~nm}$. Amount of maltose released $(\mathrm{mg})$ was measured from standard curve of maltose. One unit (U) of $\beta$ amylolytic activity was defined as the amount of enzyme releasing $1 \mu \mathrm{mol}$ of maltose equivalent per minute per $\mathrm{mL}$ from soluble starch (Sigma) under the standard assay conditions. Maximum enzyme titer was expressed as units per gram of dry mass of substrate $(\mathrm{U} / \mathrm{gdm})$.

\section{Statistical analysis of data}

All experiments were repeated thrice independently and representative data are shown as average values of triplicates. Error bars stand for percentage error of results. Error percentage below $5 \%$ was considered significant for this study.

\section{Result and discussion}

Effect of initial moisture content of medium on the production of $\beta$ amylase

Presence of moisture or water activity $\left(a_{\mathrm{w}}\right)$ in substrate plays the most critical role in SSF. Microbial activity in solid substrate is severely influenced by moisture exist in absorbed or complex form within solid matrix. The $a_{\mathrm{w}}$ of the medium has been attributed as a fundamental parameter for mass transfer of the water and solutes across the microbial cells. Variation of moisture content can directly influence microbial metabolism. Insufficient moisture may lead to poor accessibility of nutrients, insufficient diffusion of solute and gas resulting in poor microbial growth and so decreases enzyme production (Gervais and Molin 2003; Ramesh and Lonsane 1990). On the other hand, higher moisture content results in decrease of enzyme production as it decreases interparticle space of solid substrate and changes particle structure. This sterically hinder microbial growth, reduce gas volume and decreases rate of diffusion and ultimately affects oxygen transfer (Perez-Guarre et al. 2003). The optimum moisture content in SSF depends on organism and the substrate used for fermentation. In general, moisture level has found to vary between 30 and $85 \%$. Due to lesser demand of water during growth, only fungi and yeast were termed as suitable microorganisms for SSF. It was thought that due to high water activity requirement, bacterial cultures might not be suitable for SSF. However, experience has shown that bacterial cultures can be well managed and manipulated for SSF processes (Ramesh and Lonsane 1990; Anto et al. 2006; Baysal et al. 2003). Result of the present study indicated (Fig. 1) that optimum initial moisture level of substrates was $50 \%$ for CF, $60 \%$ for B, A, YPS, RH and $70 \%$ for S, WB, RP. After $41 \mathrm{~h}$ of incubation at $37{ }^{\circ} \mathrm{C}$, highest enzymatic production were recorded in case of $\mathrm{B}(120.34 \mathrm{U} /$ $\mathrm{gdm})$ followed by WB (119.79 U/gdm) and S (115.08 U/ $\mathrm{gdm}$ ) in their optimum moisture level. Other substrates showed little production at the same time. Different optimum moisture level indicated variation of moisture holding capacity of the substrates. A similar finding was reported for $\alpha$ amylase production by $B$. licheniformis using SSF (Lonsane et al. 1985) where optimum moisture level was varied between 60 and $75 \%$. Higher than expected level of moisture content $(90 \%)$ was also reported in case of Thermomyces lanuginosus ATCC 58157 by SSF on wheat bran (Kunamneni et al. 2005).

Effect of inoculum load on $\beta$ amylase production

Higher inoculum concentration increases moisture level to a significant extent. This is due to free excess liquid that forms an additional diffusional barrier (Baysal et al. 2003). On the other hand, lower inoculum load delays desired microbial growth that ultimately affects enzymatic production. Several studies indicated that 20-30\% inoculum load was optimum for microbial activity (Pandey et al. 1999). SSF using B. subtilis DJ5 indicates that for $B, S$, WB, CF, A, YPS, RH only $10 \%$ inoculum concentrations is sufficient for maximum enzyme production (Fig. 2). Maximum enzyme production was observed in $\mathrm{B}$ 
Fig. 1 Effect of initial moisture content (\% by mass per volume) on $\beta$ amylase production in SSF system. Process standard: inoculum load-10\% by volume per mass, incubation time- $41 \mathrm{~h}$, incubation temperature $-37^{\circ} \mathrm{C}$, media $\mathrm{pH}-6.9$

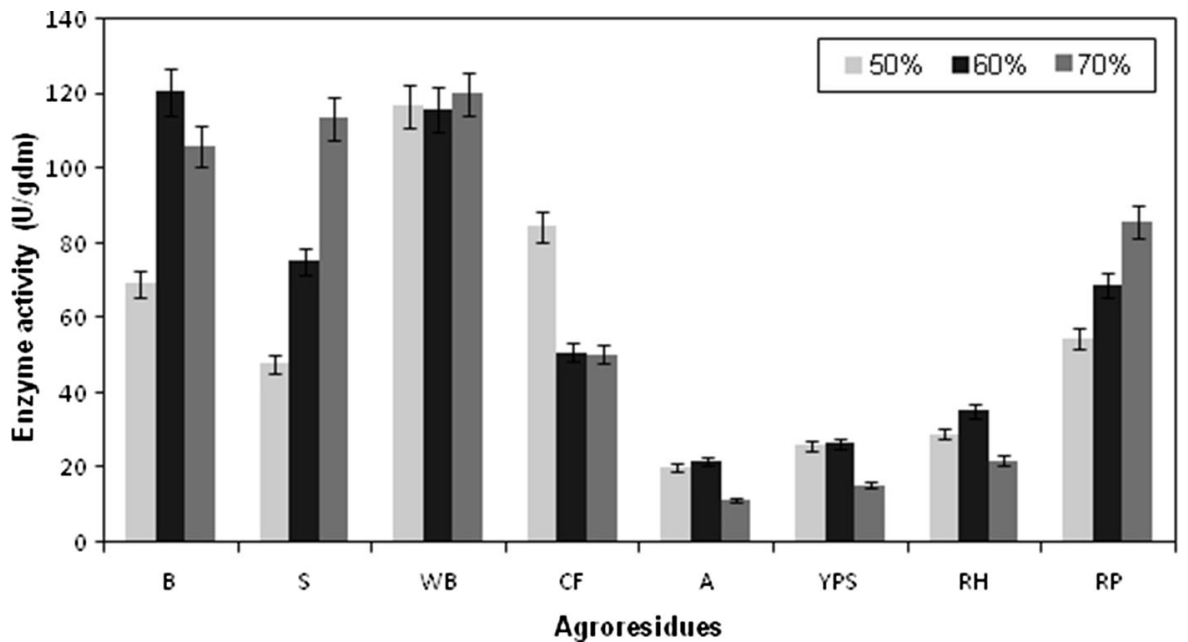

Determination of optimum incubation time on $\beta$ amylase production

The incubation time is governed by substrate availability towards microbial growth and enzyme production (35). Among the different substrates tested in this study, maximum production was recorded after $25 \mathrm{~h}$ for A, YPS, RH, $\mathrm{RP}, 41 \mathrm{~h}$ for B, WB, CF and $45 \mathrm{~h}$ for $\mathrm{S}$ (Fig. 5). Though maximum production was earlier in case of A, YPS, RH, production titer was not very high. RP showed a higher production $(93.75 \mathrm{U} / \mathrm{gdm})$ after $25 \mathrm{~h}$ of incubation at $45^{\circ} \mathrm{C}$. B and WB showed highest enzyme production of $120.34 \mathrm{U} / \mathrm{gdm}$ and $119.79 \mathrm{U} / \mathrm{gdm}$, respectively after $41 \mathrm{~h}$ of incubation. $\mathrm{S}$ somehow delayed enzyme production. After $45 \mathrm{~h}$ of incubation maximum production of $115.08 \mathrm{U} / \mathrm{gdm}$ was recorded. Higher enzyme titer obtained after $41 \mathrm{~h}$ of incubation in B and WB indicates that it was suitable for growth of $B$. subtilis DJ5. A gradual decrease in enzyme yield was recorded on further extension of fermentation period beyond optimum level. Similar findings have been reported (Sivaramakrishnan et al. 2006; Ramesh and Lonsane 1987) indicating enzyme degradation due to accumulation of toxic and protein denaturing agent in the medium.

Comparison of enzyme production in different substrate

From the Table 1, it is evident that barley is the best substrate for $\beta$ amylase production followed by wheat bran (WB). Arrowroot (A) was found to be the poorest substrate for SSF.

Susceptibility of substrates towards enzymatic breakdown can be explained in the light of molecular frameworks of the substrate molecule. Scanning electron microscopy has found depressions on surfaces of dehydrated or wet starch granules randomly distributed over granule surfaces (maize, sorghum) or clustered equatorially 
Fig. 2 Effect of inoculums fraction (\% by volume per mass) on $\beta$ amylase production in SSF system. Process standard: initial moisture $\mathrm{B}, \mathrm{A}, \mathrm{YPS}, \mathrm{RH}$ and $70 \%$ for $\mathrm{S}$, WB, RP, incubation time$41 \mathrm{~h}$, incubation temperature$37{ }^{\circ} \mathrm{C}$, media $\mathrm{pH}-6.9$ content-50\% for $\mathrm{CF}, 60 \%$ for

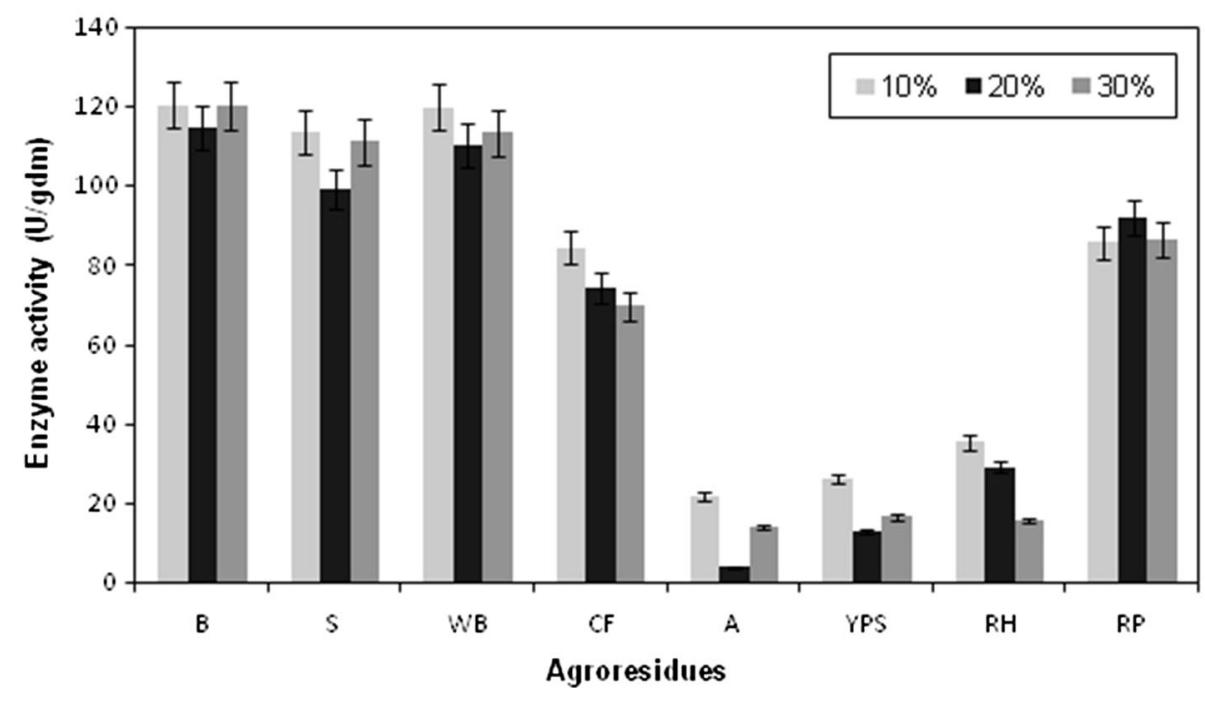

Fig. 3 Effect of $\mathrm{pH}$ on $\beta$ amylase production by SSF system. Process standard: initial moisture content $-50 \%$ for $\mathrm{CF}$, $60 \%$ for B, A, YPS, RH and $70 \%$ for $S$, WB, RP, inoculums load $-10 \%$ for B, S, WB, CF, A, YPS, RH and $20 \%$ for RP, incubation time- $41 \mathrm{~h}$, incubation temperature $-37^{\circ} \mathrm{C}$, media $\mathrm{pH}-6.9$

Fig. 4 Effect of incubation temperature on $\beta$ amylase production by SSF system. Process standard: initial moisture content $-50 \%$ for $\mathrm{CF}$, $60 \%$ for B, A, YPS, RH and $70 \%$ for $S$, WB, RP, inoculums load $-10 \%$ for B, S, WB, CF, A, YPS, RH and $20 \%$ for RP, incubation time $-41 \mathrm{~h}$, media $\mathrm{pH}-6.9$
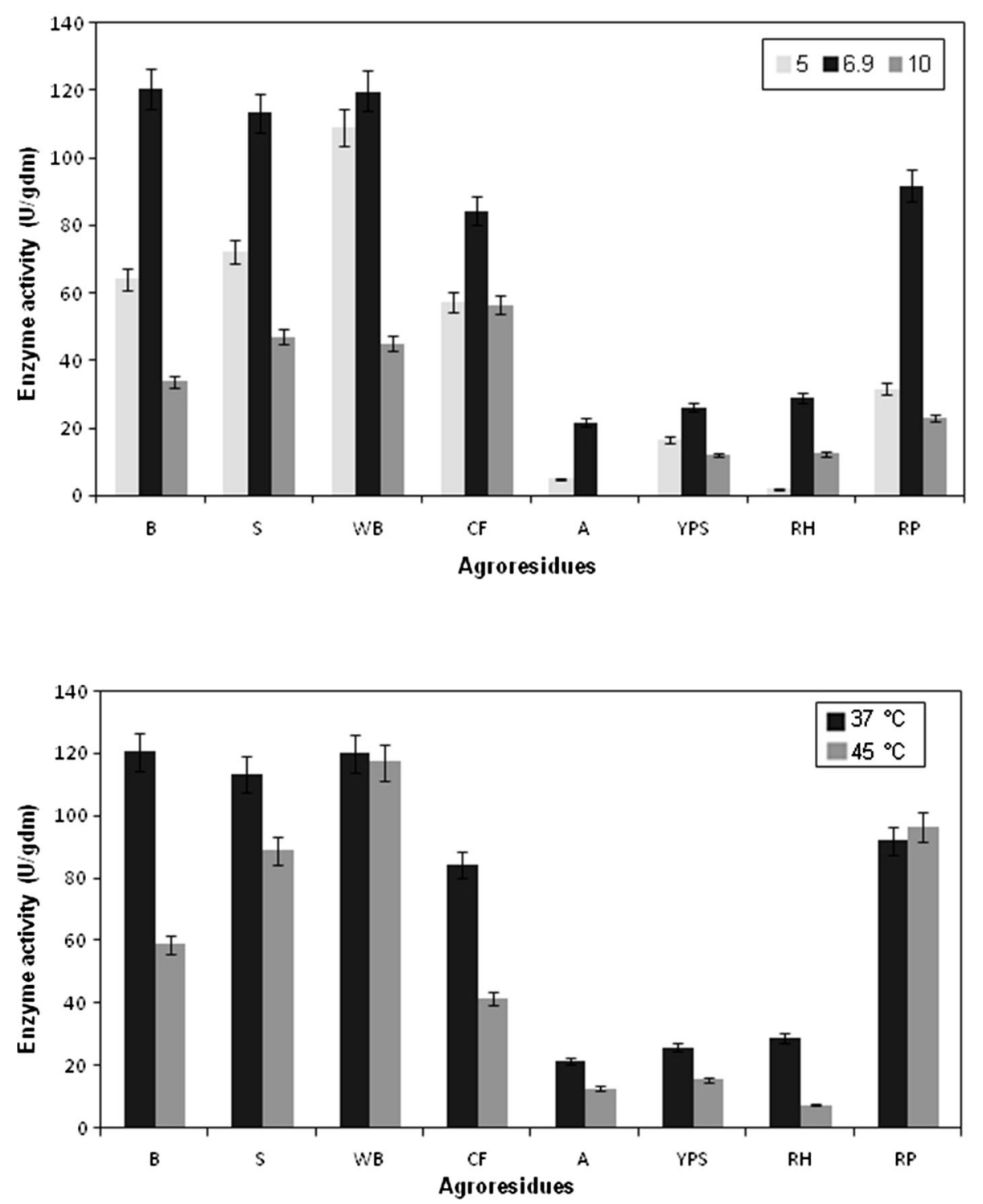
Fig. 5 Effect of incubation time on $\beta$ amylase production by SSF system. Process standard: initial moisture content $-50 \%$ for $\mathrm{CF}, 60 \%$ for $\mathrm{B}, \mathrm{A}, \mathrm{YPS}, \mathrm{RH}$ and $70 \%$ for $\mathrm{S}$, WB, RP, inoculums load$10 \%$ for $\mathrm{B}, \mathrm{S}, \mathrm{WB}, \mathrm{CF}, \mathrm{A}$, YPS, RH and $20 \%$ for RP, incubation time- $41 \mathrm{~h}$, incubation temperature- $37{ }^{\circ} \mathrm{C}$, media $\mathrm{pH}-6.9$

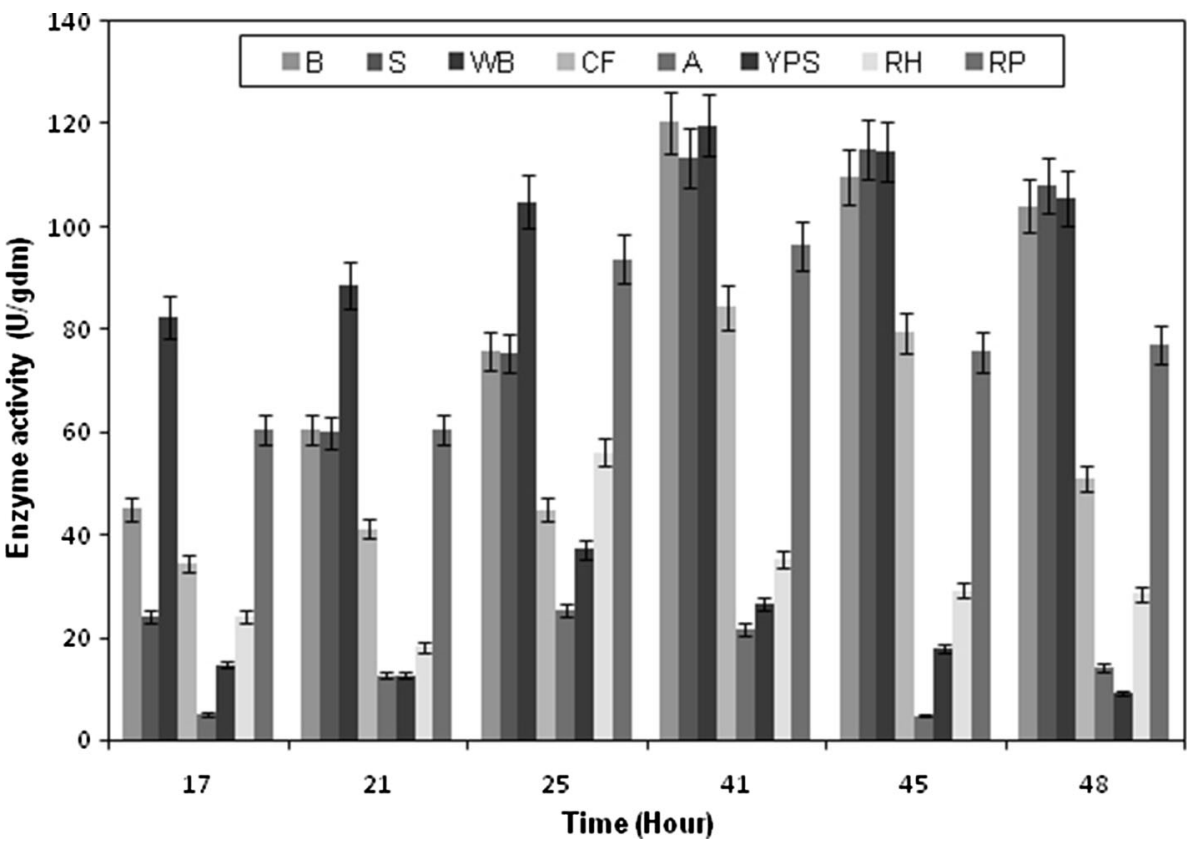

Table 1 Comparison of $\beta$ amylase production by Bacillus subtilis DJ5 using different agroresidues under SSF

\begin{tabular}{lllllll}
\hline Substrate & $\begin{array}{l}\text { Moisture } \\
\text { content }(\%)\end{array}$ & $\begin{array}{l}\text { Inoculum } \\
\text { load }(\%)\end{array}$ & $\begin{array}{l}\text { Optimum } \\
\text { incubation time }(\mathrm{h})\end{array}$ & $\begin{array}{l}\text { Medium } \\
\mathrm{pH}\end{array}$ & $\begin{array}{l}\text { Incubation } \\
\text { temperature }\left({ }^{\circ} \mathrm{C}\right)\end{array}$ & $\begin{array}{l}\text { Maximum } \\
\text { Production }(\mathrm{U} / \mathrm{gdm})\end{array}$ \\
\hline $\mathrm{S}$ & 70 & 10 & 45 & 6.9 & 37 & 115.08 \\
$\mathrm{~B}$ & 60 & 10 & 41 & 6.9 & 37 & 120.34 \\
WB & 70 & 10 & 41 & 6.9 & 37 & 119.79 \\
CF & 50 & 10 & 41 & 6.9 & 37 & 84.29 \\
A & 60 & 10 & 25 & 6.9 & 37 & 25.15 \\
YPS & 60 & 10 & 25 & 6.9 & 37 & 37.11 \\
RH & 60 & 10 & 25 & 6.9 & 37 & 56.05 \\
RP & 70 & 20 & 25 & 6.9 & 45 & 93.75 \\
\hline
\end{tabular}

(wheat, barley) and are not seen on arrowroot starch granules (Robertson et al. 2006). The depressions may be architecturally enzyme-susceptible regions. For digestion of raw starch granules, enzymatic attack is primarily focused to equatorial regions. Relatively mild amylase activity was suggested to be the result of poor presentation of surface molecules to the enzyme and to the $\alpha$-D (1-4) bond specificity. Poor surface presentation of $\mathrm{A}$ and rice resulted in lower production of maltose, hence showed lower enzymatic activity.

Barley is the fourth largest cereal grain crop produced worldwide (after wheat, rice, and corn) and is used as rice substitute in many countries. Literature survey indicates that barley is the most underutilized cereal grain in terms of human consumption (Bhatty 1993). This results in huge wastage of this crop worldwide. On the other hand, WB is obtained while processing of wheat. Since it is not a product of human consumption, it is also accumulated in large quantities. This will be a gentleman's idea to use these in SSF that will minimize wastage.

This study has indicated barley is the most promising substrate for B. subtilis DJ5 followed by WB for $\beta$ amylase production using SSF. Both substrates result in nearly similar productivity of $\beta$ amylase. So utilization of this culture in SSF using B and WB as substrate will be beneficial not only from industrial point of view, but it will also serve to lower wastage and environmental pollution.

\section{Conclusion}

The use of SSF for the production of hyperthermostable $\beta$ amylase using B. subtilis DJ5 is an economical and environment friendly process and is an alternative method of management of agroresidues or agro-wastes. Barley and/or wheat bran is the best substrate for the production of enzyme. 
Maximum production can be achieved in a very short time (41 h) using $10 \%$ inoculum load and incubating at $37{ }^{\circ} \mathrm{C}$.

Acknowledgments Authors thank the Principal, Bidhannagar College for providing all sorts of infrastructural facility for carrying out the study. This work was financially supported by University Grants Commission (F. No. 33-124/2007 (SR) dated 6th March, 2008).

\begin{tabular}{ll}
\multicolumn{2}{l}{ Nomenclature } \\
B & Barley \\
S & Sattu \\
WB & Wheat bran \\
YPS & Yellow peas split \\
CF & Corn flour \\
A & Arrowroot \\
RH & Rice husk \\
RP & Rice powder \\
SSF & Solid state fermentation \\
SmF & Submerged fermentation
\end{tabular}

\section{References}

Achi OK, Njoku-Obi ANU (1992) Production of raw starch saccharification amylase by Bacillus alvei grown on different agricultural substrates. World J Microbiol Biotechnol 8:206-207. doi: 10.1007/BF01195849

Alva S, Anupama J, Salva J, Chiu YY, Vyshali P, Shruti M et al (2007) Production and characterization of fungal amylase enzyme isolated from Aspergillus sp. JGI 12 in solid state culture. Afr J Biotechnol 6:576-581

Anto H, Trivedi U, Patel K (2006) Alpha amylase production by Bacillus cereus MTCC 1305 using solid state fermentation. Food Technol Biotechnol 44:241-245

Balkan B, Ertan F (2007) Production of alpha amylase from Penicillium chrysogenum under solid state fermentation by using some agricultural by products. Food Technol Biotechnol 45:439-442

Baysal Z, Uyar F, Aytekin C (2003) Solid-state fermentation for production of $\alpha$-amylase by a thermotolerant Bacillus subtilis from hot-spring water. Process Biochem 38:1665-1668. doi: 10.1016/S0032-9592(02)00150-4

Bellon-Maurel V, Orliac O, Christen P (2003) Sensors and measurements in solid-state fermentation: a review. Process Biochem 38:881-896. doi:10.1016/S0032-9592(02)00093-6

Bernfeld P (1955) Amylase $\alpha$ and $\beta$. Methods Enzymol 1:149-158. doi:10.1016/0076-6879(55)01021-5

Bhatty RS (1993) Nonmalting uses of barley. In: MacGregor AW, Bhatty RS (eds) Barley chemistry and technology. Am Assoc Cereal Chem, St. Paul, pp 355-417

Gangadharan D, Sivaramakrishnan S, Nampoothiri KM, Pandey A (2006) Solid culturing of Bacillus amyloliquefaciens for alpha amylase production. Food Technol Biotechnol 44:269-274

Gervais P, Molin P (2003) The role of water in solid state fermentation. Biochem Eng J 13:85-101. doi:10.1016/S1369703X(02)00122-5

González GV, Torres EF (2006) Why solid-state fermentation seems to be resistant to catabolite repression? Food Technol Biotechnol 44:397-406

Gustavsson J, Cederberg C, Sonesson U, van Otterdijk R, Meybeck A (2011) Global food losses and food waste: extent, causes and prevention. International congress of food and agriculture organization of the United Nations, Düsseldorf

Haddadin MSY, Abu-Reesh IM, Haddadin FAS, Robinson RK (2001) Utilisation of tomato pomace as a substrate for the production of vitamin B-12 - a preliminary appraisal. Bioresource Technol 78:225-230. doi:10.1016/S0960-8524(01)00018-9

Haki GD, Rakshit SK (2003) Developments in industrially important thermostable enzymes: a review. Bioresource Technol 89:17-34. doi:10.1016/S0960-8524(03)00033-6

Haq IU, Ashraf H, Iqbal J, Qadeer MA (2002) Biosynthesis of $\alpha$ amylase by chemically treated mutant of Bacillus subtilis. J Biol Sci 2:73-75. doi:10.3923/jbs.2002.73.75

Hoogschagen M, Zhu Y, van As H, Tramper J, Rinzema A (2001) Influence of wheat type and pretreatment on fungal growth in solid-state fermentation. Biotechnol Lett 23:1183-1187. doi: 10.1023/A: 1010577414126

Kim S, Dale BE (2004) Global potential bioethanol production from wasted crops and crop residues. Biomass Bioenergy 26:361-375. doi:10.1016/j.biombioe.2003.08.002

Kunamneni A, Kuttanpillai SK, Singh S (2005) Response surface methodological approach to optimize the nutritional parameters for enhanced production of $\alpha$-amylase in solid-state fermentation by Thermomyces lanuginosus. Afr J Biotechnol 4:708-716

Lonsane BK, Ghildyal NP, Budiatman S, Ramakrishna SV (1985) Engineering aspects of solid state fermentation. Enzyme Microb Technol 7:258-265. doi:10.1016/0141-0229(85)90083-3

Pandey A (2003) Solid-state fermentation. Biochem Eng J 13:81-84. doi:10.1016/S1369-703X(02)00121-3

Pandey A, Soccol CR (2000) Economic utilization of crop residues for value addition-a futuristic approach. J Sci Ind Res 59:12-22

Pandey A, Selvakumar P, Soccol CR, Nigam P (1999) Solid-state fermentation for the production of industrial enzymes. Curr Sci $77: 149-162$

Pandey A, Nigam P, Soccol CR, Soccol VT, Singh D, Mohan R (2000a) Advances in microbial amylases. Biotechnol Appl Biochem 31:135-152. doi:10.1042/BA19990073

Pandey A, Soccol CR, Mitchell D (2000b) New developments in solidstate fermentation, I: bioprocesses and applications. Process Biochem 35:1153-1169. doi:10.1016/S0032-9592(00)00152-7

Pandey A, Soccol CR, Nigam P, Soccol VT, Vandenbergh LPS, Mohan R (2000c) Biotechnological potential of agro-industrial residues, II: cassava bagasse. Bioresource Technol 74:81-87. doi:10.1016/S0960-8524(99)00143-1

Pandey A, Soccol CR, Nigam P, Soccol VT (2000d) Biotechnological potential of agro-industrial residues I. Sugarcane bagasse. Bioresource Technol 74:69-80. doi:0.1016/S0960-8524(99)00142-X

Pandey A, Szakacs G, Soccol CR, Leon JAR, Soccol VT (2001) Production, purification and properties of microbial phytases. Bioresource Technol 77:203-214. doi:10.1016/S0960-8524(00) 00139-5

Parfitt J, Barthel M, Macnaughton S (2010) Food waste within food supply chains: quantification and potential for change to 2050 . Phil Trans R Soc 365:3065-3081. doi:10.1098/rstb.2010.0126

Peralta-Perez MR, Saucedo-Castaneda G, Gutierrez-Rojas M, Campero A (2001) $\mathrm{SiO}_{2}$ xerogel: a suitable inert support for microbial growth. J Sol-Gel. Sci Technol 20:105-110. doi:10.1023/A: 1008784802596

Perez-Guarre N, Torrado-Agrasar A, Lopez-Macias C, Pastrana L (2003) Main characteristics and application of solid substrate fermentation. Electron J Environ Agric Food Chem 2:243-350

Poddar A, Gachhui R, Jana SC (2011a) Cell immobilization of Bacillus subtilis DJ5 for production of novel hyperthermostable extracellular $\beta$ amylase. Aust J Basic Appl Sci 5:456-464

Poddar A, Gachhui R, Jana SC (2011b) Saccharification of native starches by hyperthermostable $\beta$ amylase from Bacillus Subtilis 
DJ5 and optimization of process condition for higher production of maltose. Int J Appl Biotechnol Biochem 1:221-230

Ramesh MV, Lonsane BK (1987) A novel bacterial thermostable alpha amylase system produced under solid state fermentation. Biotechnol Lett 9:501-504. doi:10.1007/BF01027460

Ramesh MV, Lonsane BK (1990) Critical importance of moisture content of the medium in $\alpha$ amylase production by Bacillus licheniformis M27 in solid state fermentation medium. Appl Microbiol Biotechnol 33:501-505. doi:10.1007/BF00172541

Ray RR, Nanada G (1996) Microbial $\beta$ amylases: biosynthesis, Characteristics and Industrial Applications. Crit Rev Microbiol 22:182-299. doi:10.3109/10408419609106459

Robertson GH, Wong DWS, Lee CC, Wagschal K, Smith MR, Orts WJ (2006) Native or raw starch digestion: a key step in energy efficient biorefining of grain. J Agric Food Chem 54:353-365. doi:10.1021/jf051883m
Shen GJ, Saha B, Lee Y, Bhatnagar L, Zeikus J (1988) Purification and characterization of a novel thermostable $\beta$ amylase from Clostridium thermosulfurogenes. Biochem J 254:835-840

Shiau JR, Hung HC, Jeang CL (2003) Improving the thermostability of raw starch digesting amylase from Cytophaga sp. by site directed mutagenesis. Appl Environ Microbiol 69:2383-2385. doi:10.1128/AEM.69.4.2383-2385.2003

Sivaramakrishnan S, Gangadharan D, Nampoothiri KM, Soccol CR, Pandey A (2006) $\alpha$-Amylases from Microbial Sources-An Overview on Recent Developments. Food Technol Biotechnol 44:173-184

van der Maarel MJEC, van der Veen B, Uitdehaag JCM, Leemhuis H, Dijkhuizen L (2002) Properties and applications of starchconverting enzymes of the $\alpha$-amylase family. J Biotechnol 94:137-155. doi:10.1016/S0168-1656(01)00407-2 